\title{
Participation in recreation camps and its relation \\ to self-efficacy and positive future view \\ at Mansoura University students
}

\section{Dr / Mohamed Elsaid Elsaid Matar \\ Faculty of Physical Education - Mansoura University}

\section{Research introduction and problem:}

Education has become at the present time one of the main pillars which any reform or progress is built for society and university education has become an urgent social necessity imposed by the nature and speed of contemporary social and economic changes and developments and therefore interest in it has increased and it is seen as a national investment for society, the university is considered one of the educational institutions What is important and which is a direct and main reason for investing and upgrading human minds through employing energies, capabilities on sound educational and scientific foundations.

The recreational activities provided by the university are considered one of the important and vital educational methods and methods in preparing and raising students as they contribute an influential role in achieving the educational goals of society through investing free time for students and achieving their multiple desires and needs through participation in the various and various recreational activities. (16: 198).

Recreational camps are one of the important educational pillars and a good way to take advantage of free time and gain many experiences and skills in the open air, where students participating in it can get to know many different cultures, ideas and trends. (12: 400).

Recreational camps are one of the activities that are characterized by a simple life and free from any assignment or complexity, which gives the student many opportunities to train in many different situations and life matters that may contribute to showing the feelings of the interior and its feelings and expressing it as well as showing talent and capabilities and getting to know them clearly and then a necessity Focus on it so that the student can achieve compatibility with himself and with the environment in which he lives and thus feel that he is a useful and effective member of society.

Self-efficacy is one of the important variables in the psychological field that guides and influences the behavior of students, and contributes to achieving their personal goals. The beliefs that each student possesses and believes in regarding his capabilities, and personal skills have an effective and influential role in controlling the environmental environment in which he lives, which contributes to Increased realization of the ability to achieve personal achievement and achieve the successful performance of any work. (2: 620)

The self-efficacy of any student is based on the beliefs and self-judgments emanating from him regarding his personal abilities to do any specific behaviors or things, self-efficacy 
within its framework is not just a set of general feelings, but a self-evaluation by the student for himself about what he can perform or do it of tasks and activities and extending his personal ability to persevere and endure and make an effort to accomplish it, It also depends on the degree of flexibility the student has and enjoys when dealing with the difficult challenges facing and the complex situations that he is exposed to, as well as his identification of the difficulties and ways to overcome them, as well as his resistance to failure and washout. (1: 290).

Self-efficacy beliefs among students play an important role in their personal lives as they contribute to shaping their emotional state and feelings, as well as ways to behave in different situations that they may be exposed to. Students with a high degree of self-efficacy enjoy a great deal of confidence in themselves and seek initiation and initiative in performing difficult tasks and activities while students with low effectiveness avoid performing tasks or activities that may require the need for perseverance or continued effort, They may see it as a failure for them and may not achieve their personal goals, which may significantly affect students, their attitudes towards life, and their outlook for the future.

Nada El-Sherbiny (2016) emphasizes that the student's view of self-efficacy largely determines the extent of the effort exerted in the performance of tasks and activities and the extent of perseverance and determination in them. Students with a positive outlook seek to make a great and double effort towards achieving their goals and aspirations while students with negative perceptions reduce their efforts And their energies are affected by surrender and retreat quickly. (17: 48). The positive view of the student towards a future is considered to be a strong launch towards achieving happiness in his personal life, in which it sends a spirit of ambition and achievement and the pursuit of self-affirmation and achieving personal goals and hopes as well as future aspirations.

Essam Ahmed (2018), citing Seligman (2002), notes that it is necessary to develop the capabilities and characteristics of students' personality as it is considered an effective bulwark, as it is a preventive bulwark and a strong defense against psychological and social pressures and its negative consequences, and that attention to human capabilities and features contribute to achieving happiness and enjoyment With life, overcome failures and washout and avoid anxiety of the unknown and the future. (6: 126)

inasmuch as the society is going through many problems, challenges, and rapid and successive changes in all fields, whose effects are reflected on university students, where they are exposed to many challenges, obstacles, and many problems, and the study burdens and psychological pressures of various kinds that constitute a psychological burden that affects them and their confidence in themselves and their personal abilities, In addition to most students feeling anxious and fearful about the future because of the challenges and the problems it poses imposed by contemporary life, Especially with the increasing and high unemployment rates and the difficulty in obtaining suitable job opportunities, therefore most students, especially those who graduate, believe that they will face an unknown and mysterious future. Thus, the research problem becomes clear, as this belief generates a feeling among most students of frustration, tension and psychological distress when engaging and thinking in the future, Consequently, it 
may lead to a decrease in self-efficacy and their sense that life is not worthy of attention. Therefore, the absence or decrease of self-efficacy leads to an increase in many negative aspects and their spread among most students Such as lack of social communication skills, lack of respect for dates, dependency on colleagues, feeling indifferent and not being able to plan well for the future. This is confirmed by the study of Mohammed Fayez (2019), in the presence of some negative manifestations among many students, such as lack of confidence in personal abilities, lack of social relations, laziness and dependency in the performance of works or study activities. (14: 6).

Thus it becomes clear the importance of self-efficacy among students so that their personality is better built and given that the future depends on the nature of the capabilities and skills of students themselves and their talents more than relying on factors of luck or circumstances of destiny, And given that the ability to good handling and effectively with events and situations in life needs students with high self-efficacy and a positive personality capable of dealing with various situations, crises and difficult circumstances.

And given that recreational camps are a fertile field and an ideal environment for building and developing students 'personality and meeting their different needs as they provide countless opportunities from actual practices of situations and experiences, Also, there are potential capabilities and abilities within the student that may not appear within the family environment or in the field of study at the university and find no place to start in except through participating in recreational camps such as preparing for a healthy social life, The ability to team work and cooperate with others, self-reliance, developing a sense of student value and his role in society, In addition to developing some meanings, spiritual values, sentimental feelings, a sense of psychological reassurance, and a sense of relief within environment and world of the camp, Which may increase the student's sense of confidence in himself and his ability to achieve success and the ability to achieve, and then increase the feeling of psychological satisfaction and personal happiness, Which may generate a positive feeling about the student's outlook of his life and future, which prompted the researcher to study participation in recreational camps and its relationship to self-efficacy and a positive outlook of the future for Mansoura University students.

\section{Research purpose :}

This research aims to know the relationship between participation in recreational camps, self-efficacy, and a positive outlook of the future for Mansoura University students, by answering the following questions:

1. What is the level of participation in recreational camps for Mansoura University students?

2. What is the level of self-efficacy among Mansoura University students?

3. What is the level of positive outlook for the future of Mansoura University students ?

4. What is the correlation between participation in recreational and self-efficacy camps and a positive outlook for the future of Mansoura University students? 
5. What is the significance of the differences to participate in recreational and self-efficacy camps and the positive outlook for the future of Mansoura University students, which is attributed to (gender, college)?

\section{Search procedures :}

The researcher used the descriptive method in the survey method due to its suitability to the nature of the research, as well as the statistical approach that is consistent with the treatment of his study data collected through the scale of participation in recreational camps, the scale of self-efficacy, and the scale of positive outlook of the future.

\section{Research Society and Sample:}

The research community is represented by Mansoura University students.The researcher selected the research sample randomly, and its number was (602) from Mansoura University students participating in the recreational camps for the basic sample and (50) for the exploratory sample from Mansoura University students participating in the recreational camps and from outside the basic sample.

\section{Data collection tools:}

1. Basic Data" form for the research sample. Appendix (1).

2. The scale of participation in recreational camps consists of (71) items distributed over (6) dimensions - prepared by the researcher Appendix (2).

3. The self-efficacy scale consists of (51) items distributed on (5) dimensions - prepared by the researcher Appendix (3).

4. positive outlook of the future consists of (17) items - prepared by the researcher Appendix (4).

5. to identify the relationship between participation in recreational camps and self-efficacy and a positive outlook of the future for university students Mansoura.

Sincerity test, the scale of participation in recreational camps, the measure of self-efficacy, and the measure of positive outlook of the future for Mansoura University students:

To verify the appropriateness of the vocabulary of the participation scale in recreational camps, the measure of self-efficacy, and the measure of positive outlook of the future among Mansoura University students, the researcher applied the three measures to an exploratory sample of (50) Mansoura University students from within the community and outside the research sample in the period of (8) (8/2/2020 AD to 13/2/2020 AD).

The researcher used the sincerity of the internal consistency to calculate the validity of the vocabulary and dimensions of the participation scale in recreational camps, the measure of self-efficacy and the measure of positive outlook of the future for Mansoura University students. By finding the simple correlation coefficient for Pearson (Person) between the vocabulary belonging to each dimension, by finding the correlation coefficient between each individual and the total degree of the dimension as well as between the total score for each dimension and the sum of the scale scores. 
The stability of the measure of participation in recreational camps, the measure of selfefficacy, and the measure of positive outlook of the future for Mansoura University students:

The stability values of the participation scale in recreational camps range (0.76- 0.84$)$, while the values of the stability of the self-efficacy scale range (0.77-0.81), while the values of the stability of the self-effectiveness scale (0.85), which indicates the stability of the three measures.

\section{Field study:}

After reassure of the factors of honesty and consistency, the researcher applied the scale of participation in recreational camps, the scale of self-efficacy, and a measure of positive outlook of the future for Mansoura University students, On the basic study sample of (602) students from Mansoura University participating in recreational camps, from (17/2/2020) to $(12 / 3 / 2020 \mathrm{AD})$, and after completing the application of the two measures, the data has been emptied in preparation for conducting the appropriate statistical Processing.

\section{What is the level of participation in recreational camps among Mansoura University students?}

From table (1) it is clear that the level of the hubs of participation in recreational camps according to the opinions of students, the study sample came at a high level, where the relative weight of the hubs ranged between $(73.063 \%$ to $80.785 \%$ ), This may be because camp activities have the interests of most students, as they are one of the favorite activities for their souls, as they achieve physical and nervous comfort and relaxation from the trouble of university study, It provides them with opportunities for freedom of movement, start-up and creativity, in addition to working to prepare to enjoy the scenic environmental and natural scenes and the impact it leaves on the hearts and emotions of the participating students, The camps are also one of the activities that most students enjoy at the university, away from the crowds of contemporary civil life and the associated noise, pollution and resulting problems that may not end, This gives students the spirit of renewal, departure, optimism, psychological balance, and a sense of joy and happiness towards personal life. Appendix (5).

This is consistent with the study of Ayman Freihat (2019) (3), Muhammad Fayez (2019) (14), Hind Al-Jabali (2017) (10), Fang Yan Y (2011) (7), Hazem Mansour (2008)( 9), which made it clear that recreational camps are among the most important activities that interest most of the students at the university and that they obtain their interest because of its many benefits in acquiring various life skills.

\section{What is the level of self-efficacy among Mansoura University students?}

From table (2) it is clear that the levels of the subjects of self-efficacy according to the opinions of students, the study sample came at a high level, where the relative weight of the hubs ranged between $(70.074 \%$ to $83.933 \%$ ), This may be due to the dimensions of self-efficacy, which can be raised through training and practice. This is what is available in recreational camps, as it is an appropriate and ideal environment that enables students participating in their various activities to express themselves and their ideas, And their sentimental feelings with absolute freedom and to communicate with others successfully, as well as through active 
participation they can continuously train to endure the burdens of personal and social responsibility and the ability to face various pressures and perseverance in completing team work with colleagues, Which increases students 'confidence in themselves, their capabilities and their ability to achieve their personal goals, and consequently their behavior change and their thinking patterns are affected for the better, which makes students' lives characterized by positive and ambitious and looking to the future with a spirit of optimism, which leads them to more work and success in the study and personal life. Appendix (6).

This is consistent with the study of Mohammed Fayez (2019) (14), Hind Al-Jabali (2017) (10), Christina Caprice, Marina Mondo, Cristina, C, Marina, M. (2017) (4), Sharky, Jia Si Shr K, Jyh c, (2016) (20), which indicated that students participating in camp activities acquire social communication experiences and skills and the ability to solve problems, selfconfidence and dependence, improve competence and self-ability and that perseverance, persistence and the pursuit of success are an indication of the self-efficacy of students.

\section{What is the level of positive outlook for the future of Mansoura University students?}

From table (3) it is clear that the level of positive view of the future according to the opinions of students, the study sample came at a high degree, where the relative weight of the total scale reached (78.990\%), This may be due to the recreational camps having an effective role in the education of students, as it provides opportunities for full integration into the activities practiced, and its results will be to develop the personality of students and provide them with new experiences and provide them with many values and skills that help in achieving a great amount of harmony, harmony and positive communication with others, the ability to accomplish, succeed and increase the opportunities for creative and positive thinking to solve problems, which creates a great sense of high self-efficacy that leads to raising morale and increasing students' sense of contentment and desire for self-realization and the continuous pursuit of success to achieve ambition and personal targets, Which motivates students to look positively towards the future and to have positive feelings towards life and look at them from the bright side and thus expect the best in the future, This is consistent with the study of Christina Caprice, Marina Mondo, Cristina, C, Marina, M. (2017) (4), Rossella Flange, Maria Elvira, Elisabetta Rossella F, Maria E, Elisabetta S (2014) (18), Dalia Youssef (2008) (5), who demonstrated that students enjoy a high level of positive thinking about the future and future expectations, that the future soul is more powerful and desirable, that the positive outlook of life In the future, it strengthens the strong influence of optimism and coping strategies on life satisfaction, thus helping students to retain the value and meaning of life and to enhance their ability to drive achievement and achieve success. Appendix (7).

\section{What is the correlation between participation in recreational camps and self-efficacy, and a positive outlook of the future for Mansoura University students?}

From table (4), it is clear that there is a statistically significant correlation between participation in recreational and self-efficacy camps and a positive outlook of the future for Mansoura University students, as the calculated value of " $R$ " is higher than its scheduled value at the level of significance 0.05 , As the correlation coefficients between the total mark for participation in recreational camps and self-efficacy (0.171) and the overall degree of 
participation in recreational camps and positive perception (0.162), and between the overall degree of self-efficacy and positive perception (0.585), Which means that the marks of the sample individuals in the dimensions of the measure of self-efficacy (self-confidence, emotional control, social communication, persistence, seeking success) and the total mark of the scale and the scale of the positive view of the future have been closely related to a positive indication of their degrees in the scale of participation in recreational camps, The significance level was (0.05), and this result means that the more students participate in recreational camps, the more it helps to increase self-efficacy in its various dimensions and increase the sense of positive outlook for the future. Appendix (8).

This may be because recreational camps are one of the activities that students accept to Practice in and participate in, with internal motives and without being forced to get out of the burdens of school life and the routine of daily routine life and the desire to spend leisure time and invest in learning life skills associated with nature and emptiness, As well as taking advantage of the experiences and opportunities granted by coexistence within the camp environment as it is an ideal environment for learning and training through practice as well as the acquisition of experiences and skills related to social life, which effectively affects the building and formation of students 'personality and enhances personal competency skills and self-efficacy in its various aspects, Thus helping them to improve their lifestyle and way of life and develop their capabilities to increase communication and positive and effective participation in the surrounding social environment, Which gives students a sense and feeling that they have the skills and capabilities necessary to achieve their goals and future aspirations and thus the ability to achieve success and excellence in the personal and professional life in the future, Which creates a positive feeling that life has a meaning and value, and thus increases satisfaction with it and becomes brighter and more joyful, which reflects a feeling among students about the positive outlook for the future.

This is consistent with the study of Mohamed Fayez (2019) (14), Shaima Abdel Razek (2016) (19), Muhammad Abdullah, Samah Al-Qaddour (2016) (15), Rossella Flange, Maria Elvira, Elisabetta Sajoni Rossella F, Maria E, Elisabetta S (2014) (18), which showed an association between self-efficacy and the goal of life and orientation towards the future and that camps help students change their ideas and accomplish tasks and activities in a renewed manner and acquire life skills, as well as the effect of self-efficacy on the actual self and future self of students Where the more likely students are to personally control the conditions in their lives, the greater their expression of a positive self-concept in the present and the future.

What is the significance of the differences to participate in recreational and self-efficacy camps and the positive outlook for the future among Mansoura University students, which is attributed to (gender, college) ?

It is clear from Table (5) that there are statistically significant differences between males and females in participating in recreational camps, self-efficacy, and a positive outlook of the future for Mansoura University students, which are attributed to gender, in favor of males as the calculated value of $(\mathrm{T})$ in all areas is greater than its value (t)Scheduled at the significance level (0.05), This may be due to the nature of the males and their future aspirations to obtain a social position and obtain a suitable job opportunity for their specialization and scientific 
standing in order to achieve their goals and aspirations and to have the desired social status, Consequently, their lives change for the better in the future, while some social customs and traditions, especially in the countryside, that limit the ambitions of the university girl in the future and some of them are satisfied with university degrees due to marriage, parenting and family affairs in the future. Appendix (9).

This is in line with the study of Mohamed Fayez (2019) (14), Christina Caprice, Marina Mondo, Cristina, C, Marina, M. (2017) (4), Fang, Y (2011) (7), which showed a clear difference between students where (male) students are higher in life skills and that male students are more optimistic about the future and future expectations and are more satisfied with their lives than female students.

There are no statistically significant differences between males and females in (concept, activities, social communication, perseverance and persistence) as the calculated value of (T) in all fields is less than the value of the table $(\mathrm{T})$ at the level of significance (0.05), may be due to The recreational needs of male students are not different from those of female students at this university level.

This is in line with the study of Walaa Yusef (2016) (23) Muhammad Al-Dhahabi (2005) (13), which showed that there were no statistically significant differences in terms of gender (male, female) in the concept and areas of practice activities and the dimensions of students' self-efficacy.

\section{What is the significance of the differences to participate in recreational and self-efficacy camps and the positive outlook for the future among Mansoura University students, which is attributed to (college) ?}

It is clear from Table (6) that there are statistically significant differences between the practical and theoretical colleges in participating in recreational and self-efficacy camps and the positive outlook of the future for Mansoura University students that are attributed to the college in favor of the practical colleges where the value of $(\mathrm{t})$ calculated in all areas is greater From the table (T) value at the significance level (0.05), This may be due to the nature of study in practical colleges, the large number of exams in it, the desire of most students to get rid of nervous and psychological stress and the burdens of school life, as well as the need to spend the free time available in the open air and green spaces and enjoy the natural and aesthetic landscapes in the surrounding environment, in addition to the desire of some students from Practical colleges in actual training to take advantage of the resources and capabilities of the environment surrounding the camp in an attempt to develop their practical skills. Appendix (10).

Fang, Y (2011) (7), Hazem Mansour (2008) (9), who explained that there were differences , according to the variable of the study nature in favor of practical colleges.

There are no statistically significant differences between students of practical and theoretical colleges in (concept, goals, means of attraction, control of emotions, the pursuit of success) as the calculated value of (T) in all fields is less than the value of the table (T) at the level of significance (0.05)), It may be due to the fact that the need and motivations of students from the practical colleges for recreational activities and practices are not different from the 
need and motivations of the students from the theoretical colleges for recreational activities and practices. This is consistent with the study of Mohamed Al-Dhahabi (2005) (13), there are no statistically significant differences in terms of the nature of the study (theoretical, practical) towards the goals of recreational camps activities.

\section{research deductions:}

Based on the results of this research and in light of the method used and the limits of the sample and data collection tools, the researcher reached the following conclusions:

1. The awareness and realization of most university students about the concept of recreational camps, through the actual practice of its various activities.

2. The interest of most students in achieving goals (social and psychological) in order to participate in community service, as well as developing mental and emotional health and achieving relaxation and neurological comfort, in order to restore the psychological balance of students.

3. Most students agreed on the availability of criteria to be observed in recreational camps activities, the foremost of which was that they are compatible with the customs and traditions of society.

4. Participation in the activities of the social field and the public service field for recreational camps has the greatest interest for most students. The activity of visiting patients and caring for the poor followed by the activity of environmental clean-up projects at the forefront of arranging recreational camps activities.

5. Social media came at the front of the resources that most students receive the attention of, as it became one of the attractive and controlling means for communication and communication between students.

6. The most important means of attraction to participate in recreational camps activities is to activate the university's website to educate students and guide them towards participation.

7. There is a high level of self-efficacy and a positive outlook for students participating in recreational camps.

8. There is a positive correlation between students' participation in recreational and selfefficacy camps and a positive outlook of the future.

9. There are no statistically significant differences between males and females in (concept, activities, social communication, persistence and perseverance), There are statistically significant differences in the remaining dimensions of participation in recreational camps and self-efficacy and a positive view of the future for university students according to the gender variable in favor of males.

10. Lack of statistically significant differences between dimensions (concept, goals, means of attraction, emotion control, pursuit of success), There are significant differences in the remaining dimensions of participation in recreational and self-efficacy camps and a positive outlook of the future for university students according to the college variable in favor of practical colleges.

\section{Research recommendations:}


1. it is important for the Ministry of Higher Education's interest in developing a strategic plan and implementing it for the idea of recreational camps week in universities to serve the environment and society and include it in the ministry's plans in the academic year.

2. The need for the university to interests in coordinating relations and holding cooperation protocols with the various recreational institutions in order to maximize the benefit from the capabilities of those institutions in the field of camps, for the benefit of participants student .

3. The university is keen on providing family education and awareness programs for parents about the importance of the camps and inviting them to participate in the activities of university camps and attending the honoring ceremony for students.

4. it is important for different media inerestes to develop a media strategy aimed at changing and adjusting the trends of the a broad audience towards recreational camps, consolidating their concept and clarifying the returns from them at all personal and social levels.

5. it is important of working to guide students at the university to the type of programs and activities that are appropriate to their capabilities, inclinations and desires, so that they accept the practice with strong motivations and achieve satisfaction and the goal of participation.

6. it is important for the university to interests encouraging teaching staff to participate in recreational camps, providing material and moral incentives, and providing them with appropriate times for effective participation.

7. The necessity of providing the university with the recreational facilities, tools and materials required in the recreational camps, as well as facilitating the ability of borrowers to borrow these tools.

\section{References}

1. Alaa al-Shaarawy: Self-efficacy and its relationship to some motivational variables among high school students, Journal of the Faculty of Education, Mansoura University, No. 44, 2013 AD.

2. Attaf Mahmoud: Self-efficacy and its relationship to the stress of life of married students at Al-Aqsa University, Journal of the Islamic University for Educational and Psychological Studies, Volume 20, Issue 1, 2012 AD.

3. Ayman Frehat: The role of youth camps in promoting values among university youth, published research, Journal of Approaches, Approaches to Publishing and Cultural Industries, No. 37, 2016.

4. Cristina, C, Marina, M,: Coping strategies optimism and life satisfaction among firstyear university students in Italy: gender and age differences, Journal Of Higher Education, Vol:46(4), ),pp643-654, 2017.

5. Dalia Youssef: The meaning of life and its relationship to the motivation of academic achievement and satisfaction with studying among university students, unpublished Master Thesis, Faculty of Physical Education, Zagazig University, 2008. 
6. Essam Ahmed: Behavioral cognitive counseling program to develop positive thinking skills to improve the quality of life and reduce future anxiety for high school students, published research, Journal of Scientific Research in Education, Ain Shams University, College of Girls, No. 19, 2018.

7. Fang,Y: Astudy on the relationship between University students regulatory emotional self- efficacy and positive thinking, phd, Huazhong Normal University, 2011.

8. Goltan Hijazi, Hassan Mahdi, Atef Abou Ghaly: Picture of the future and positive thinking and their relationship to crises among Palestinian youth in the governorates of Gaza, published research, International Journal of Research in Education and Psychology, Scientific Publishing Center, University of Bahrain, Volume IV, First Issue, 2016 AD.

9. Hazem Mansour: value study of outdoor recreation programs, unpublished Master Thesis, Faculty of Physical Education, Mansoura University, 2008.

10.Hind Al Jabali: The role of camps in the group's service to develop social skills among university youth, published research, Journal of Social Work, Egyptian Society of Social Workers, No. 58, Part 5, 2017 CE.

11.Hussam Goda: Value study of recreational culture for Mansoura University students, unpublished Master Thesis, Faculty of Physical Education, Mansoura University, 2008.

12.Kamal Darwish, Amin El-Khouly: Recreation and free time, history and philosophy, needs, programs and activities, i, Cairo, Dar Al-Fikr Al-Arabi, 2001 AD.

13. Mohammed al-Dhahabi: Building a scale to evaluate student activities at Mansoura University from a recreational perspective, an unpublished Master Thesis, Faculty of Physical Education, Mansoura University, 2005 AD.

14.Mohamed Fayez: The role of recreational camps in developing some life skills for Mansoura University students, unpublished Master Thesis, Faculty of Physical Education, Mansoura University, 2019.

15.Muhammad Abdullah, samah elqadour: Self-efficacy and its relationship to the goal of life, a field study on a sample of students from the University of Aleppo, published research, Journal of the Federation of Arab Universities for Education and Psychology, Volume 14, No. 1, 2017 AD.

16. Muhammad Al-Hamami and Aida Abdulaziz: Recreation between theory and practice, 3rd floor, Cairo, Book Center for Publishing, 2006 AD.

17.Nada El-Sherbiny: Perceived management and its relationship to self-efficacy and a sense of school affiliation with public and private prep School teachers, PhD thesis, Faculty of Education, Mansoura University, 2016 AD.

18.Rossella F, Maria E, Elisabtta S: Self- efficacy Beliefs and Representation of self and psychology Longitudinal study with psychology university students, Journal Of Procardia- Social and Behavioral Sciences, Vol:140, pp295-299, 2014. 
19. Shaima Abdel Razek: The camps and their role in developing creativity among university youth, published research, Journal of Social Work, Egyptian Society of Social Workers, Issue 56, Part 2, 2016.

20.Shr J, Jyh c: Perception of Academic Self-Efficacy and Academic Hardiness in Taiwanese University students, Journal Of International congress on Advanced Applied informatics (IIAL- AAI) , ),pp1189-1199, 2016.

21.Sorensen,N: Effectiveness of Mindful Walking Combined with Self- efficacy Messages on Attention Mindfulness, and Self- efficacy in University students, Journal Of ProQuest Dissertations and Theses Global, 2018.

22. TahanyAbdul Salam: Recreation and recreational education, Dar Al-Fikr Al-Arabi, Cairo, 2001.

23.Walaa Yousef: Self-efficacy and its relationship to social responsibility, unpublished Master Thesis, Faculty of Education, Damascus University, 2016.

\section{Appendix (1)}

Initial data

- Name (optional)

Gender (Male) (Female)

-The college (Theoretical) (Practical)......... 


\section{Appendix (2)}

The scale of outdoor recreation activities for Mansoura University students:

First: Please put a sign $(\sqrt{ })$ in front of each item that you think represents the concept of your recreational camps according to the response (balance of appreciation) that you agree with.

\begin{tabular}{|c|c|c|c|c|}
\hline $\mathbf{N}$ & The concept of recreational camps & yes & $\begin{array}{c}\text { To } \\
\text { some } \\
\text { extent }\end{array}$ & no \\
\hline 1. & Practical practice of some situations in nature and outdoor. & & & \\
\hline 2. & $\begin{array}{l}\text { A group of activities that students can participate in to serve } \\
\text { the community. }\end{array}$ & & & \\
\hline 3. & $\begin{array}{l}\text { Activities and projects that are carried out at leisure and } \\
\text { achieve psychological satisfaction and happiness. }\end{array}$ & & & \\
\hline 4. & $\begin{array}{l}\text { An educational method that Initialize opportunities for } \\
\text { participants to exchange experiences. }\end{array}$ & & & \\
\hline 5. & $\begin{array}{l}\text { Students gathered for a day or more during which the joint } \\
\text { interaction is carried out to implement some projects. }\end{array}$ & & & \\
\hline 6. & $\begin{array}{l}\text { An educational way to achieve a comprehensive and } \\
\text { integrated education for students participating in its programs } \\
\text { and activities. }\end{array}$ & & & \\
\hline 7. & $\begin{array}{l}\text { Organizing a meeting between students under the supervision } \\
\text { of a recreational pioneer qualified for the nature and outdoor } \\
\text { life. }\end{array}$ & & & \\
\hline 8. & $\begin{array}{l}\text { An open-air educational method that provides participants } \\
\text { with life skills. }\end{array}$ & & & \\
\hline
\end{tabular}


Second: Please put a sign $(\sqrt{ })$ in front of each item that you think represents one of the goals of recreational camps that you can practice according to the response (balance of appreciation) that matches your opinion:

\begin{tabular}{|c|c|c|c|c|}
\hline 1. & Feeling free and running & & & \\
\hline 2. & Self-expression & & & \\
\hline 3. & Enjoy a new lifestyle & & & \\
\hline 4. & Competition with others & & & \\
\hline 5. & Going to new places & & & \\
\hline 6. & Learn and practice new activities at leisure & & & \\
\hline 7. & gratification the tendency to creativity and innovation & & & \\
\hline 8. & Development of skills and experiences related to nature. & & & \\
\hline 9. & gratification the motive for movement. & & & \\
\hline 10. & Fitness development. & & & \\
\hline 11. & Enjoy good health. & & & \\
\hline 12. & Revitalization of the body and vitality. & & & \\
\hline 13. & Practicing a healthy democratic life. & & & \\
\hline 14. & making new friends. & & & \\
\hline 15. & $\begin{array}{l}\text { Increased sense of belonging to the university and the . } \\
\text { surrounding community }\end{array}$ & & & \\
\hline 16. & Participation in national celebrations and Popular festivals. & & & \\
\hline \multicolumn{5}{|c|}{$\begin{array}{l}\text { Third: Please put a sign }(\sqrt{ }) \text { in front of each item that you think represents one of the criteria } \\
\text { that must be met in your recreational camps according to the response (the balance of } \\
\text { appreciation) that matches your opinion: }\end{array}$} \\
\hline $\mathbf{N}$ & Standards & yes & $\begin{array}{c}\text { To } \\
\text { some } \\
\text { extent }\end{array}$ & no \\
\hline 1. & $\begin{array}{l}\text { Safety and security factors are available to students in the . } \\
\text { camp }\end{array}$ & & & \\
\hline 2. & $\begin{array}{l}\text { Activities are consistent with the customs and traditions of the } \\
\text { society. }\end{array}$ & & & \\
\hline 3. & $\begin{array}{l}\text { Programs and activities are commensurate with the available } \\
\text { material and human capabilities. }\end{array}$ & & & \\
\hline 4. & $\begin{array}{l}\text { The activities are consistent with the previous recreational } \\
\text { experience of the participants. }\end{array}$ & & & \\
\hline 5. & The camps respond to students' needs and interests. & & & \\
\hline 6. & $\begin{array}{l}\text { The chosen activities allow the achievement of the camp's . } \\
\text { goals }\end{array}$ & & & \\
\hline 7. & $\begin{array}{l}\text { The activities are commensurate with the capabilities and } \\
\text { capabilities of the camp participants. }\end{array}$ & & & \\
\hline 8. & $\begin{array}{l}\text { Students participate in the selection of activities to be carried } \\
\text { out in the camp. }\end{array}$ & & & \\
\hline 9. & $\begin{array}{l}\text { The activities take into consideration the individual } \\
\text { differences between students. }\end{array}$ & & & \\
\hline
\end{tabular}


10. Activities are flexible and simple to implement.

Fourth: Please put a sign $(\sqrt{ })$ in front of each item that you think represents one of your favorite activities according to the response (the balance of appreciation) that matches your opinion:

\begin{tabular}{c|l|l|l|l}
\hline \hline Camp activities in the sports field & & & \\
\hline $\mathbf{1 .}$ & Matches and sports. & & & \\
\hline $\mathbf{2 .}$ & Organizing sporting events. & & & \\
\hline $\mathbf{3 .}$ & Festivals and sports competitions. & & & \\
\hline $\mathbf{4 .}$ & Sports shows. & & & \\
\hline
\end{tabular}

Camp activities in the field of public service

\begin{tabular}{l|l|l|l|l} 
1. & Blood donation campaigns. & & & \\
\hline 2. & Environmental cleaning and afforestation projects. & & & \\
\hline 3. & Work camp inside the university. & & & \\
\hline 4. & Anti-smoking and drug campaigns. & & & \\
\hline
\end{tabular}

\section{Camp activities in the social field.}

1. Charitable markets

2. Student families acquaintance parties.

3. Care for people with special needs in social institutions.

4. Visiting the sick and caring for the poor.

Camp activities in the cultural field

1. Cultural competitions.

Fourth: Please put a sign $(\sqrt{ })$ in front of each item that you think represents one of your favorite activities according to the response (the balance of appreciation) that matches your opinion:

\begin{tabular}{c|l|l|l|l}
\hline \hline $\mathbf{2 .}$ & Health education seminars. & & & \\
\hline $\mathbf{3 .}$ & Awareness campaigns for the environment week. & & & \\
\hline $\mathbf{4 .}$ & Recreational culture lectures. & & & \\
\hline \multicolumn{2}{l|}{ Camp activities in the technical field } & & & \\
\hline $\mathbf{1 .}$ & Art galleries. & & & \\
\hline $\mathbf{2 .}$ & frolic Concerts. & & & \\
\hline $\mathbf{3 .}$ & Festivals and art competitions. & & & \\
\hline $\mathbf{4 .}$ & Gifted care activities.
\end{tabular}

Fifth: Please put a sign $(\sqrt{ })$ in front of each item that you think represents one of the sources of knowledge of your recreational camps according to the response (the balance of appreciation) that matches your opinion:

\begin{tabular}{c|l|l|l|l}
\hline \hline $\mathbf{1 .}$ & friends. & & & \\
\hline $\mathbf{2 .}$ & The family. & & & \\
\hline $\mathbf{3 .}$ & University's website. & & & \\
\hline $\mathbf{4 .}$ & Supervisors of activities within the university. & & & \\
\hline $\mathbf{5 .}$ & Advertising posters. & & & \\
\hline $\mathbf{6 .}$ & (Media (newspapers, television, radio). & & & \\
\hline $\mathbf{7 .}$ & Social Media. & & & \\
\hline \hline
\end{tabular}


Sixth: Please put a sign $(\sqrt{ })$ in front of each item that you think represents one of the means of attraction to participate in your recreational camps according to the response (the balance of appreciation) that matches your opinion:

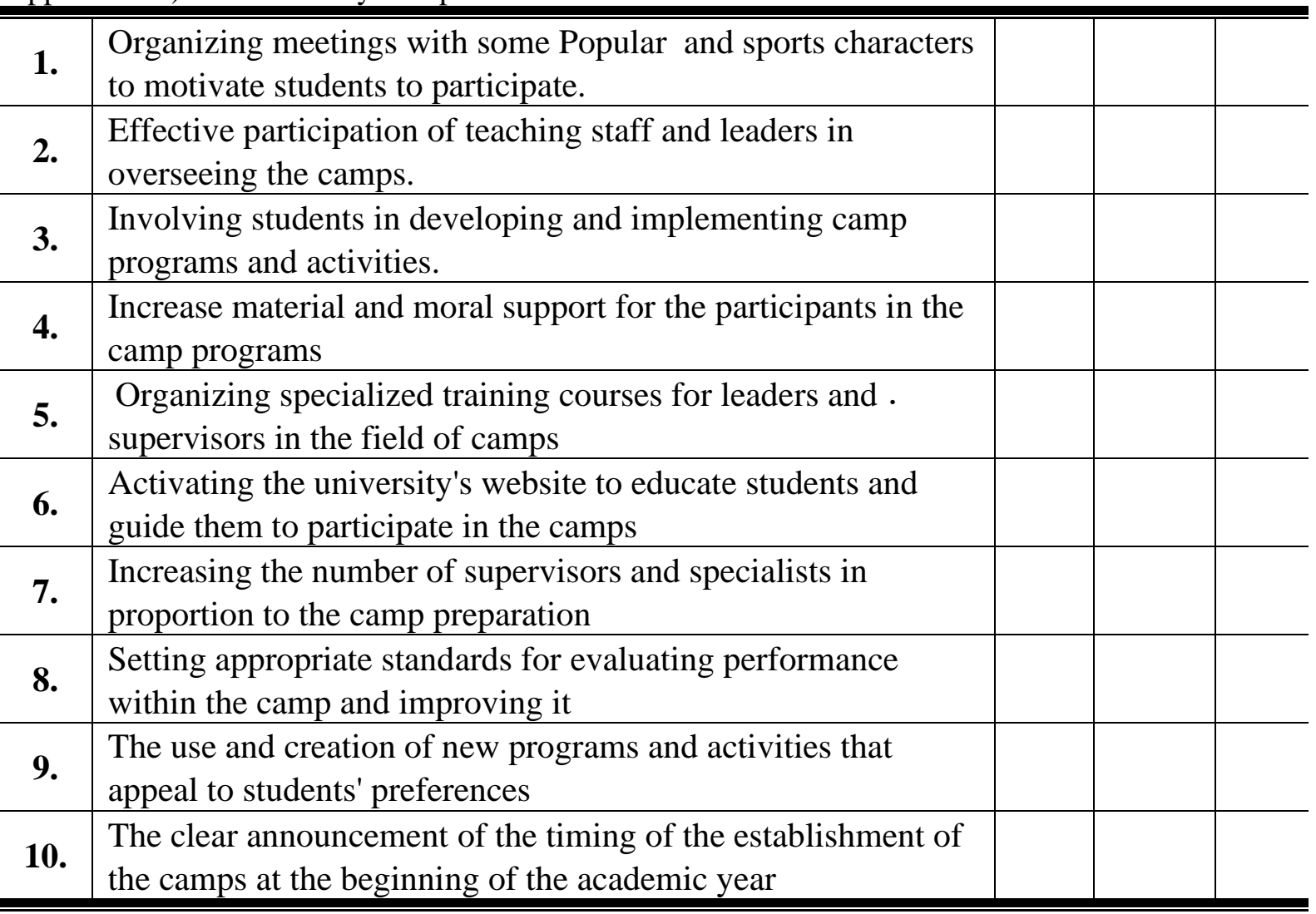

\section{Appendix (3)}

\section{Self-efficacy measure for Mansoura University students}

\begin{tabular}{c|l|c|c|c}
\hline \hline first dimension (self-confidence) & yes & $\begin{array}{c}\text { To } \\
\text { some } \\
\text { extent }\end{array}$ & no \\
\hline \hline $\mathbf{N}$ & \multicolumn{1}{|c|}{ input } & & & \\
\hline $\mathbf{1 .}$ & Express my opinions and ideas freely & & & \\
\hline $\mathbf{2 .}$ & I feel comfortable with my personal appearance. & & & \\
\hline $\mathbf{3 .}$ & other people resorts to me to solve their personal problems. & & \\
\hline $\mathbf{4 .}$ & I prefer self-reliance in the performance of academic tasks. & & & \\
\hline $\mathbf{5 .}$ & I can defend my point of view in front of others. & & & \\
\hline $\mathbf{6 .}$ & I accept advice from others and respond to them. & & \\
\hline $\mathbf{7 .}$ & I can take responsibility for any activity or work I do. & & \\
\hline $\mathbf{8 .}$ & I start with handshake when meeting others. & & \\
\hline $\mathbf{9 .}$ & I trust in my ability to perform any activity with high efficiency. & & & \\
\hline $\mathbf{1 0}$. & I have the ability to perform more than one task or activity at the & & & \\
\hline
\end{tabular}


11. I make sure to show my role and importance between my colleagues.

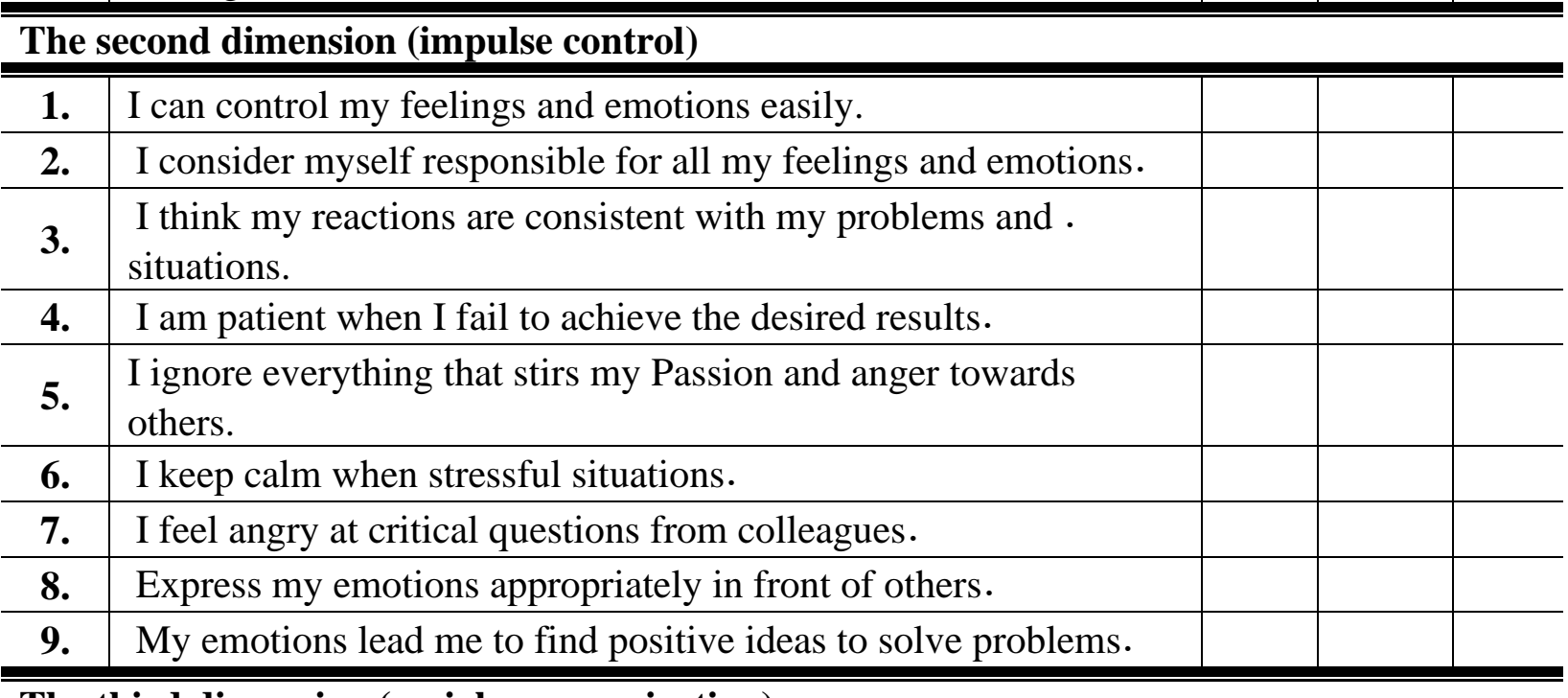

The third dimension (social communication)

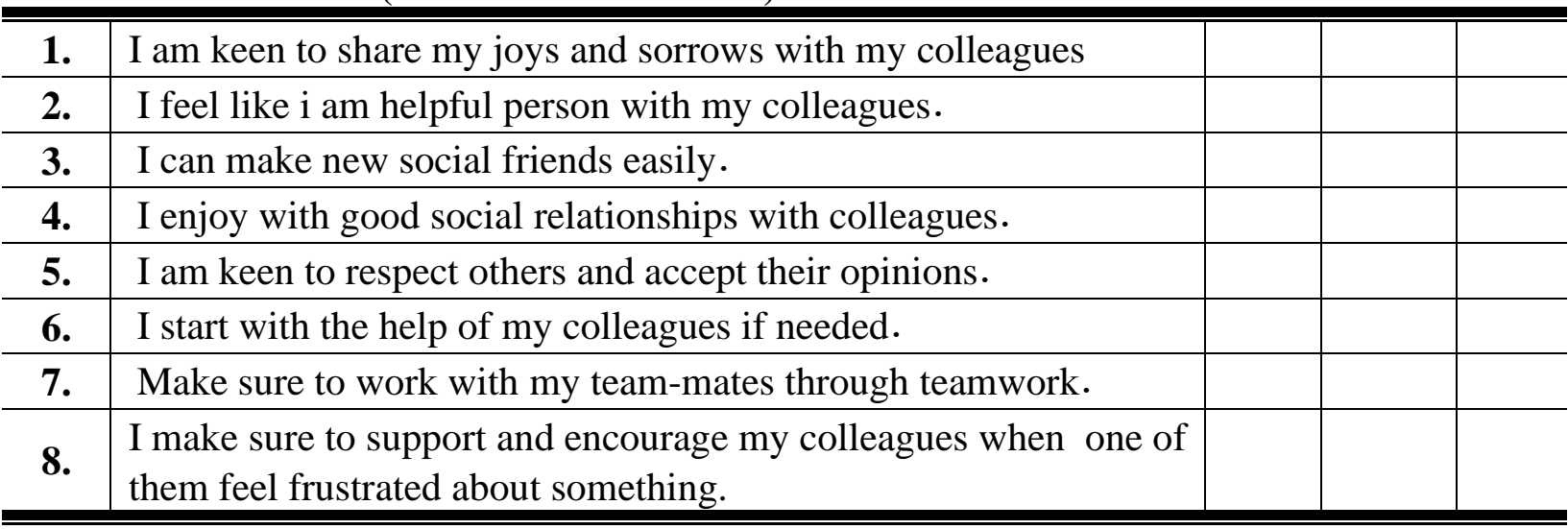

\section{The third dimension (social communication)}

\begin{tabular}{c|l|l|l|l}
\hline 9. & I think I am good at dialogue with my colleagues. & & & \\
\hline $\mathbf{1 0 .}$ & I try to dialogue and discuss with my older colleagues. & & & \\
\hline 11. & I accept my colleagues with their advantages and disadvantages. & & & \\
\hline
\end{tabular}

\section{The fourth dimension (perseverance and persistence)}

\begin{tabular}{|c|c|}
\hline 1. & I feel that I am hardworking and persistent in my studies. \\
\hline 2. & I multiply my effort to understand difficult study subjects. \\
\hline 3. & I have the patience to achieve my goals. \\
\hline 4. & $\begin{array}{l}\text { I insist on performing any work or activity that requires a level of } \\
\text { performance that exceeds my capabilities. }\end{array}$ \\
\hline 5. & $\begin{array}{l}\text { I am ready well to do any difficult task that requires effort to } \\
\text { complete it. }\end{array}$ \\
\hline 6. & $\begin{array}{l}\text { I believe that with purposefulness and volition, I can achieve } \\
\text { anything what I desire. }\end{array}$ \\
\hline 7. & I eager to finish any activity assigned to me on time. \\
\hline 8. & $\begin{array}{l}\text { I can take long hours doing any work without getting tired or } \\
\text { bored. }\end{array}$ \\
\hline
\end{tabular}




\begin{tabular}{c|l|l|l|l}
\hline 9. & $\begin{array}{l}\text { I eager repeat the attempt to learn anything I have not been } \\
\text { successful in before. }\end{array}$ & & & \\
\hline $\mathbf{1 0 .}$ & I make every effort to be distinguished in my studies. & & & \\
\hline \hline Fifth dimension ( Pursuit for success) & & & \\
\hline \hline $\mathbf{1 .}$ & I seek to know and learn all that is new in my field of study. & & \\
\hline $\mathbf{2 .}$ & $\begin{array}{l}\text { I am interested in determine my goals and aspirations with } \\
\text { precision and clarity }\end{array}$ & & & \\
\hline 3. & $\begin{array}{l}\text { I plan well to fulfill my ambitions and aspirations and do not } \\
\text { leave them to chance or luck }\end{array}$ & & & \\
\hline 4. & I seek high ratings every year. & & & \\
\hline $\mathbf{5 .}$ & I eager on developing my personal capabilities. & & \\
\hline $\mathbf{6 .}$ & $\begin{array}{l}\text { I feel that my goals and ambitions are reached from one stage to } \\
\text { another and never ends }\end{array}$ & & & \\
\hline 7. & $\begin{array}{l}\text { I think that working hard is the basis for achieving success in . } \\
\text { life }\end{array}$ & & & \\
\hline $\mathbf{8 .}$ & $\begin{array}{l}\text { I want to benefit from the expertise and experiences of others } \\
\text { success }\end{array}$ & & & \\
\hline $\mathbf{9 .}$ & I discuss my teachers about everything that i can understand. & & & \\
\hline $\mathbf{1 0}$ & I feel Sadness if I spend my spare time without any benefit. & & & \\
\hline
\end{tabular}

\section{Appendix (4)}

\section{A measure of the positive outlook for the future for Mansoura University students}

\begin{tabular}{|c|c|c|c|c|}
\hline \multicolumn{5}{|c|}{ The first dimension (self-efficacy) } \\
\hline $\mathbf{N}$ & input & yes & $\begin{array}{c}\text { To } \\
\text { some } \\
\text { extent }\end{array}$ & no \\
\hline 1. & I can plan for my future desires and aspirations easily. & & & \\
\hline 2. & I plan to be a successful and prestigious person in the future. & & & \\
\hline 3. & $\begin{array}{l}\text { I try to be creative and innovative in dealing with the difficulties } \\
\text { and challenges of life }\end{array}$ & & & \\
\hline 4. & $\begin{array}{l}\text { I see planning for the future as important to achieving my targets } \\
\text { in life }\end{array}$ & & & \\
\hline 5. & $\begin{array}{l}\text { I feel comfortable when i think about future things and ways to } \\
\text { achieve them }\end{array}$ & & & \\
\hline 6. & I expect my personal life to improve and be better in the future. & & & \\
\hline 7. & I work hard to make my life meaningful. & & & \\
\hline
\end{tabular}




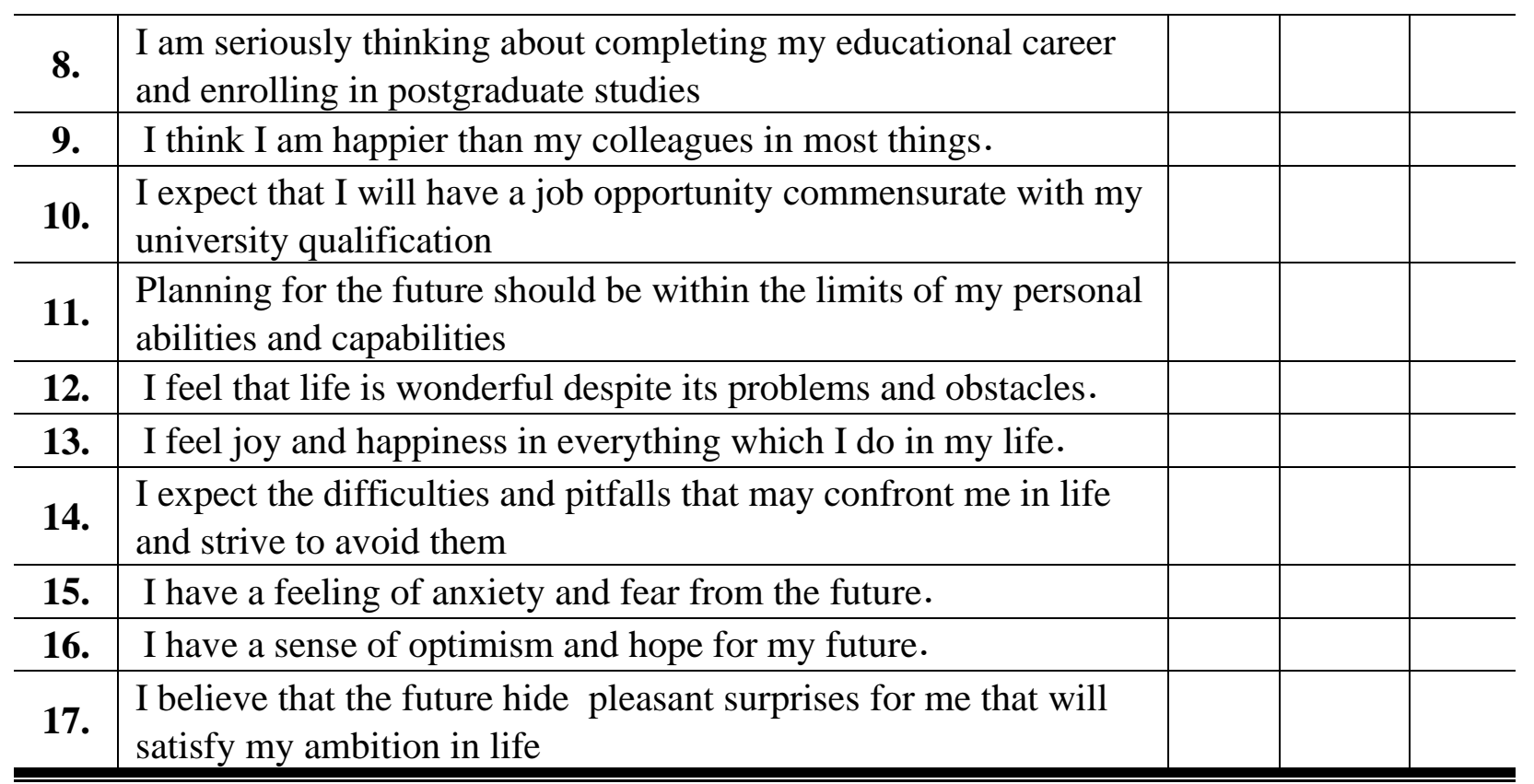

\section{Appendix (5)}

Table (1)

\section{Repetition, percentages, relative weight and level of the participation dimensions in Recreational camps for Mansoura University students}

\begin{tabular}{|c|c|c|c|c|c|c|c|c|c|c|}
\hline \multirow[b]{2}{*}{ level } & \multirow{2}{*}{$\begin{array}{c}\text { relative } \\
\text { weight } \\
\% \\
\end{array}$} & \multirow{2}{*}{$\begin{array}{l}\text { arithmetic } \\
\text { average }\end{array}$} & \multicolumn{2}{|c|}{ no } & \multicolumn{2}{|c|}{ To some extent } & \multicolumn{2}{|c|}{ yes } & \multirow{2}{*}{\multicolumn{2}{|c|}{$\overline{\text { Dimensions }}$}} \\
\hline & & & $\begin{array}{c}\text { percentage } \\
\%\end{array}$ & $\begin{array}{c}\text { Repetitio } \\
n\end{array}$ & $\begin{array}{c}\% \\
\text { percentage }\end{array}$ & Repetition & $\begin{array}{c}\% \\
\text { percentage }\end{array}$ & Repetition & & \\
\hline high & 78.958 & 2.369 & 14.888 & 717 & 33.576 & 1617 & 51.537 & 2482 & $\begin{array}{c}\text { The concept of } \\
\text { recreational } \\
\text { camps }\end{array}$ & \\
\hline high & 75.461 & 2.264 & 18.605 & 1792 & 36.4 & 3506 & 44.996 & 4334 & $\begin{array}{l}\text { Recreational } \\
\text { camp targets }\end{array}$ & \\
\hline high & 75.39 & 2.261 & 18.355 & 1105 & 38.605 & 2324 & 43.04 & 2591 & Standards & \\
\hline high & 73.325 & 2.2 & 20.307 & 489 & 39.369 & 948 & 40.324 & 971 & Sports field & \\
\hline high & 73.063 & 2.193 & 20.889 & 503 & 39.037 & 940 & 40.324 & 965 & $\begin{array}{c}\text { The field of } \\
\text { public } \\
\text { service }\end{array}$ & 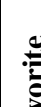 \\
\hline high & 73.188 & 2.198 & 21.968 & 529 & 36.503 & 879 & 41.528 & 1000 & $\begin{array}{c}\text { The social } \\
\text { field }\end{array}$ & E \\
\hline high & 74.003 & 2.22 & 21.844 & 526 & 34.302 & 826 & 43.528 & 1056 & $\begin{array}{c}\text { Cultural } \\
\text { field }\end{array}$ & \\
\hline
\end{tabular}




\begin{tabular}{c|c|c|c|c|c|c|c|c|c}
\hline \hline high & $\mathbf{8 0 . 7 8 5}$ & 2.425 & 14.369 & 346 & 28.904 & 696 & 56.728 & 1366 & $\begin{array}{c}\text { In the arts } \\
\text { field }\end{array}$ \\
\hline high & 75.156 & 2.254 & 19.554 & 824 & 35.406 & 1492 & 45.04 & 1898 & Sources \\
\hline high & 75.056 & 2.253 & 18.92 & 1139 & 36.993 & 2227 & 44.086 & 2654 & attractions \\
\hline \hline high & 75.439 & 2.264 & 18.647 & 7970 & 36.159 & 15455 & 45.194 & 19317 & Total marks \\
\hline \hline
\end{tabular}

\section{Appendix (6)}

Table (2)

Repetition, percentages, relative and level weight of the dimensions of selfefficacy among Mansoura University students

\begin{tabular}{|c|c|c|c|c|c|c|c|c|c|}
\hline \multirow[b]{2}{*}{ level } & \multirow{2}{*}{$\begin{array}{c}\% \\
\text { relative } \\
\text { weight } \\
\end{array}$} & \multirow[b]{2}{*}{$\begin{array}{l}\text { arithmetic } \\
\text { average }\end{array}$} & \multicolumn{2}{|c|}{ no } & \multicolumn{2}{|c|}{ To some extent } & \multicolumn{2}{|c|}{ yes } & \multirow[t]{2}{*}{ Dimensions } \\
\hline & & & $\begin{array}{c}\% \\
\text { percentage } \\
\end{array}$ & $\begin{array}{c}\text { Repetitio } \\
\text { n }\end{array}$ & $\begin{array}{c}\text { percentage } \\
\%\end{array}$ & Repetition & $\begin{array}{c}\% \\
\text { percentage } \\
\end{array}$ & Repetition & \\
\hline high & 83.933 & 2.523 & 8.457 & 560 & 30.746 & 2036 & 60.797 & 4026 & self-confidence \\
\hline $\begin{array}{c}\text { avera } \\
\text { ge }\end{array}$ & 70.074 & 2.102 & 26.102 & 1440 & 36.674 & 1987 & 36.748 & 1991 & $\begin{array}{c}\text { control } \\
\text { emotions }\end{array}$ \\
\hline high & 76.091 & 2.283 & 18.831 & 1247 & 34.008 & 2252 & 47.161 & 3123 & Social Media \\
\hline high & 74.215 & 2.226 & 26.329 & 1585 & 24.701 & 1487 & 48.970 & 2948 & $\begin{array}{l}\text { Perseverance } \\
\text { and persistence }\end{array}$ \\
\hline high & 76.832 & 2.305 & 18.654 & 1123 & 32.193 & 1938 & 49.153 & 2959 & $\begin{array}{c}\text { Pursuit of } \\
\text { success }\end{array}$ \\
\hline high & 76.229 & 2.288 & 19.396 & 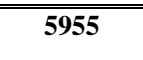 & 31.594 & 9700 & 49.010 & 15047 & total marks \\
\hline
\end{tabular}

\section{Appendix (7)}

Table (3)

Repetition, percentages, relative weight, and level of positive outlook for students of Mansoura University

\begin{tabular}{c|l|c|c|c|c|c|c|c|c}
\hline \hline \multirow{2}{*}{ level } & \multirow{2}{*}{$\begin{array}{l}\text { relative } \\
\text { weight } \\
\text { \% }\end{array}$} & \multirow{2}{*}{$\begin{array}{c}\text { arithmetic } \\
\text { average }\end{array}$} & $\begin{array}{c}\text { \% } \\
\text { percentage }\end{array}$ & Repetition & $\begin{array}{c}\text { To some extent } \\
\text { percentage }\end{array}$ & Repetition & $\begin{array}{c}\text { \% } \\
\text { percentage }\end{array}$ & Repetition & The hubs \\
\hline \hline & 78.990 & 2.370 & 15.986 & 1636 & 31.063 & 3179 & 52.951 & 5419 & $\begin{array}{c}\text { A positive } \\
\text { outlook } \\
\text { for the } \\
\text { future }\end{array}$ \\
\hline \hline
\end{tabular}




\section{Appendix (8)}

Table (4)

Correlation coefficient between participation in recreational camps and self-efficacy and a positive outlook for the future of Mansoura University students.

\begin{tabular}{|c|c|c|c|c|c|c|c|c|c|c|c|c|c|c|c|}
\hline \multirow[b]{2}{*}{$\begin{array}{l}\text { positive } \\
\text { outlook }\end{array}$} & \multicolumn{6}{|c|}{$\begin{array}{l}\text { Self-efficacy } \\
\end{array}$} & \multicolumn{7}{|c|}{ Recreational camps } & \multirow{2}{*}{\multicolumn{2}{|c|}{ Variables }} \\
\hline & $\begin{array}{l}\text { Total } \\
\text { marks }\end{array}$ & $\begin{array}{l}\text { Pursuit of } \\
\text { success }\end{array}$ & $\begin{array}{l}\text { Perseverance } \\
\text { and } \\
\text { persistence }\end{array}$ & $\begin{array}{c}\text { Social } \\
\text { communication }\end{array}$ & $\begin{array}{l}\text { emotion } \\
\text { control }\end{array}$ & $\begin{array}{c}\text { self- } \\
\text { confidence }\end{array}$ & $\begin{array}{l}\text { Total } \\
\text { marks }\end{array}$ & Attractions & Sources & Activities & Standards & purposes & $\begin{array}{c}\text { the } \\
\text { meaning }\end{array}$ & & \\
\hline $.162^{*}$ & .021 & .037 & .032 & .063 & $.124 *$ & .002 & $.397 *$ & $.075 *$ & .013 & $.276^{*}$ & .022 & $.167^{*}$ & 1 & meaning & \\
\hline .001 & .035 & $.103^{*}$ & $.144^{*}$ & $.129 *$ & .047 & .067 & $.486^{*}$ & $.351^{*}$ & .048 & $.084 *$ & $.134^{*}$ & 1 & & targets & \\
\hline $.149 *$ & $.148^{*}$ & .031 & .058 & .014 & $.080^{*}$ & $.154 *$ & $.412 *$ & .063 & $.085 *$ & $.076 *$ & 1 & & & Standards & 童 \\
\hline $.144 *$ & .016 & $.139 \%$ & $.082^{*}$ & $.083 *$ & $.118^{*}$ & $.135^{*}$ & $.785 \%$ & $.443^{*}$ & $.547 *$ & 1 & & & & Activities & 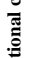 \\
\hline $.265 *$ & $.105 *$ & .043 & $.179 *$ & .032 & $.170^{*}$ & $.261^{*}$ & $.538^{*}$ & $.150^{*}$ & 1 & & & & & Sources & 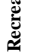 \\
\hline .008 & .020 & $.085^{*}$ & .035 & $.090^{*}$ & .021 & .017 & $.567^{*}$ & 1 & & & & & & Attractions & \\
\hline $.162^{*}$ & .071 & .038 & $.104^{*}$ & .051 & $.164^{*}$ & $.197^{*}$ & 1 & & & & & & & Total marks & \\
\hline $.798^{*}$ & $.552 \%$ & $.102^{*}$ & .013 & $.133^{*}$ & .045 & 1 & & & & & & & & Self-assurance & \\
\hline $.177^{*}$ & $.559 *$ & .025 & $.085 *$ & .056 & 1 & & & & & & & & & $\begin{array}{l}\text { emotion } \\
\text { control }\end{array}$ & \\
\hline .022 & $.423^{*}$ & $.146 *$ & .007 & 1 & & & & & & & & & & $\begin{array}{c}\text { Social } \\
\text { communication }\end{array}$ & 尊 \\
\hline $.170^{*}$ & $.222 *$ & $.127^{*}$ & 1 & & & & & & & & & & & $\begin{array}{c}\text { Perseverance } \\
\text { and persistence }\end{array}$ & 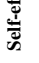 \\
\hline .007 & $.365^{*}$ & 1 & & & & & & & & & & & & $\begin{array}{l}\text { Pursuit of } \\
\text { success }\end{array}$ & \\
\hline $.585^{*}$ & 1 & & & & & & & & & & & & & Total marks & \\
\hline 1 & & & & & & & & & & & & & & positive outlo & \\
\hline
\end{tabular}

\section{Appendix (9)}

Table (5)

The significance of the differences to participate in recreational and selfefficacy camps and the positive outlook for the future among Mansoura

University students, which is attributed to (gender)

\begin{tabular}{|c|c|c|c|c|c|c|c|c|}
\hline & \multirow{2}{*}{$\begin{array}{c}\text { T } \\
\text { value }\end{array}$} & \multirow{2}{*}{$\begin{array}{c}\text { average } \\
\text { difference }\end{array}$} & \multicolumn{2}{|c|}{ Female $(n=264)$} & \multicolumn{2}{|c|}{ Male $(n=338)$} & \multirow{2}{*}{ Variables } & \\
\hline & & & $\mathbf{p} \pm$ & $\mathbf{S}$ & $p \pm$ & $\mathbf{S}$ & & \\
\hline 0.112 & 1.594 & 0.304 & 2.387 & $\begin{array}{l}18.761 \\
\end{array}$ & 2.267 & 19.065 & meaning & \multirow{6}{*}{ 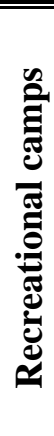 } \\
\hline 0.288 & 1.064 & -0.280 & 3.290 & 36.375 & 3.140 & 36.095 & targets & \\
\hline 0.642 & 0.466 & -0.137 & 3.742 & 22.693 & 3.449 & 22.556 & Standards & \\
\hline 0.752 & 0.317 & -0.113 & 4.303 & 54.667 & 4.402 & 54.553 & Activities & \\
\hline 0.344 & 0.948 & -0.157 & 2.066 & 15.867 & 1.986 & 15.710 & Sources & \\
\hline 0.069 & 1.823 & $\begin{array}{l}-0.328 \\
\end{array}$ & 2.176 & 22.701 & 2.201 & 22.373 & Attractions & \\
\hline
\end{tabular}




\begin{tabular}{|c|c|c|c|c|c|c|c|c|}
\hline 0.372 & 0.893 & -0.712 & 9.898 & 171.064 & 9.554 & 170.352 & Total marks & \\
\hline 0.719 & 0.360 & -0.115 & 3.905 & 27.822 & 3.866 & 27.707 & Self-assurance & \multirow{7}{*}{ 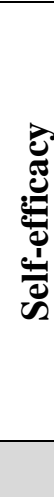 } \\
\hline 0.641 & 0.467 & -0.149 & 3.860 & 19.004 & 3.896 & 18.855 & emotion control & \\
\hline 0.619 & 0.498 & 0.106 & 2.514 & 25.030 & 2.646 & 25.136 & Social communication & \\
\hline 0.432 & 0.787 & 0.099 & 1.490 & 22.208 & 1.573 & 22.308 & $\begin{array}{c}\text { Perseverance and } \\
\text { persistence }\end{array}$ & \\
\hline 0.515 & 0.651 & 0.116 & 2.148 & 22.985 & 2.177 & 23.101 & Pursuit of success & \\
\hline 0.915 & 0.107 & 0.057 & 6.694 & 117.049 & 6.418 & 117.107 & Total marks & \\
\hline 0.090 & -0.035 & 4.779 & 40.307 & 4.623 & 40.272 & & Positive outlook & \\
\hline
\end{tabular}

Scheduled "T" value at the level of significance $(0.05)=(1.960)$

\section{Appendix (10)}

Table (6)

The significance of the differences for participation in recreational camps and self-efficacy and the positive outlook for the future among Mansoura University students, which are attributed to the (college)

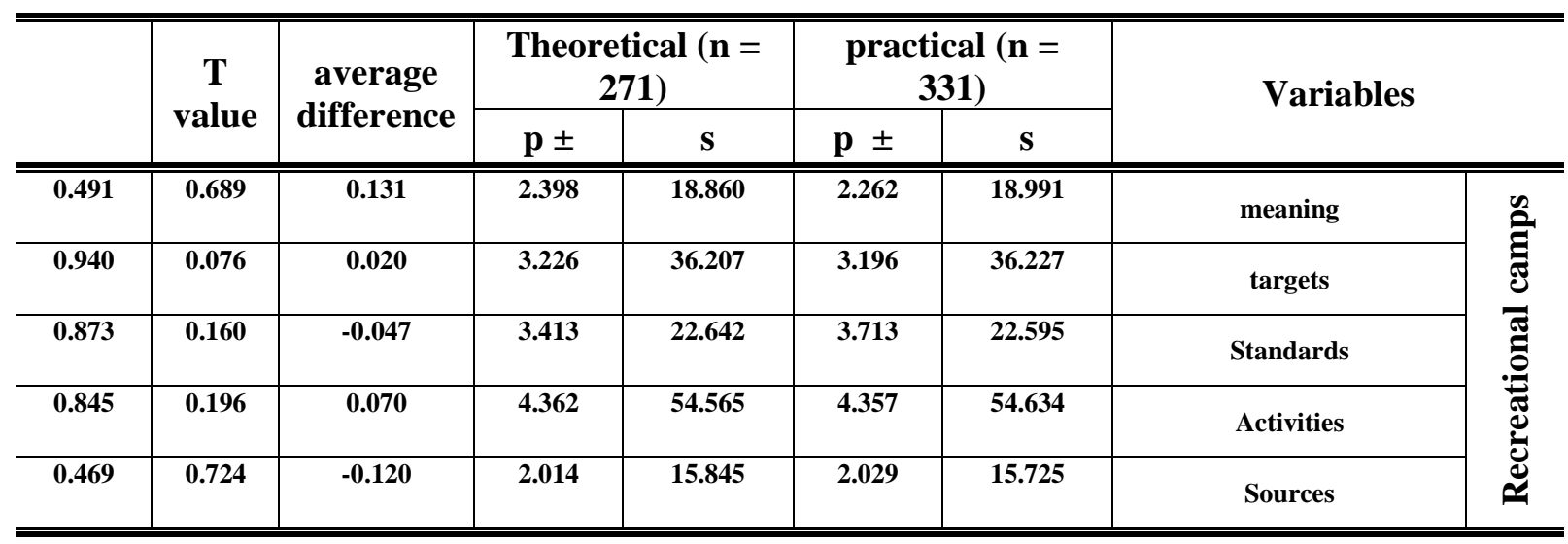




\begin{tabular}{|c|c|c|c|c|c|c|c|c|}
\hline 0.006 & 2.740 & 0.490 & 2.255 & 22.247 & 2.122 & 22.737 & Attractions & \\
\hline 0.494 & 0.684 & 0.544 & 9.915 & 170.365 & 9.537 & 170.909 & Total marks & \\
\hline 0.097 & 1.664 & -0.528 & 3.610 & 28.048 & 4.079 & 27.520 & Self-assurance & \multirow{7}{*}{ 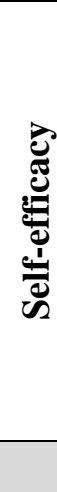 } \\
\hline 0.973 & 0.034 & -0.011 & 3.983 & 18.926 & 3.796 & 18.915 & emotion control & \\
\hline 0.642 & 0.465 & -0.099 & 2.551 & 25.144 & 2.619 & 25.045 & Social communication & \\
\hline 0.687 & 0.404 & 0.051 & 1.607 & 22.236 & 1.479 & 22.287 & $\begin{array}{l}\text { Perseverance and } \\
\text { persistence }\end{array}$ & \\
\hline 0.205 & 1.269 & 0.225 & 2.248 & 22.926 & 2.089 & 23.151 & Pursuit of success & \\
\hline 0.499 & 0.676 & -0.362 & 6.282 & 117.280 & 6.740 & 116.918 & Total marks & \\
\hline 0.345 & 0.946 & -0.363 & 4.287 & 40.487 & 4.993 & 40.124 & Positive outlook & \\
\hline
\end{tabular}

